ATOMICS INTERNATIONAL

A Division of North Americen Aviotion, Inc.

Do not remover this sheet
MAA-SR-MEMO -4 II9

This document contains I5 peoses This is copy I of series

NAA-SR-MEMOs are voorking papers and may be expanded, modified, or withdrawn at any time, and are intended for internal use only.

Thte report nay not be pabliabed withont the epproval of the Peteat Breach, AEC.

\title{
LEOAL NOTICE
}

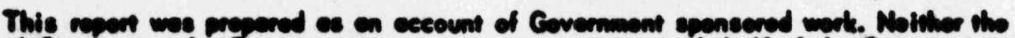

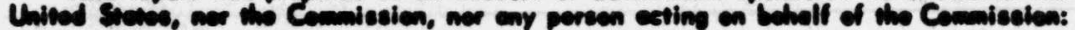

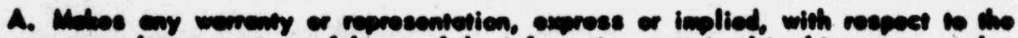

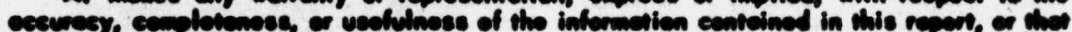

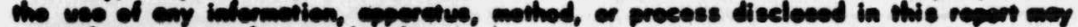

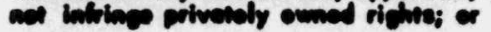

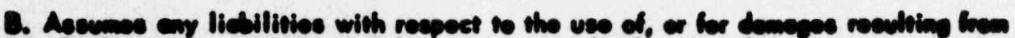

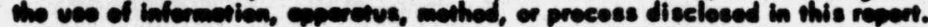

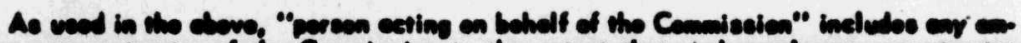

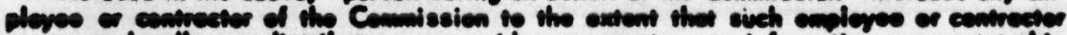

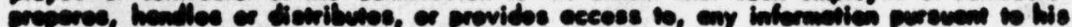

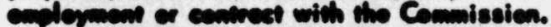




\section{DISCLAIMER}

Portions of this document may be illegible in electronic image products. Images are produced from the best available original document. 


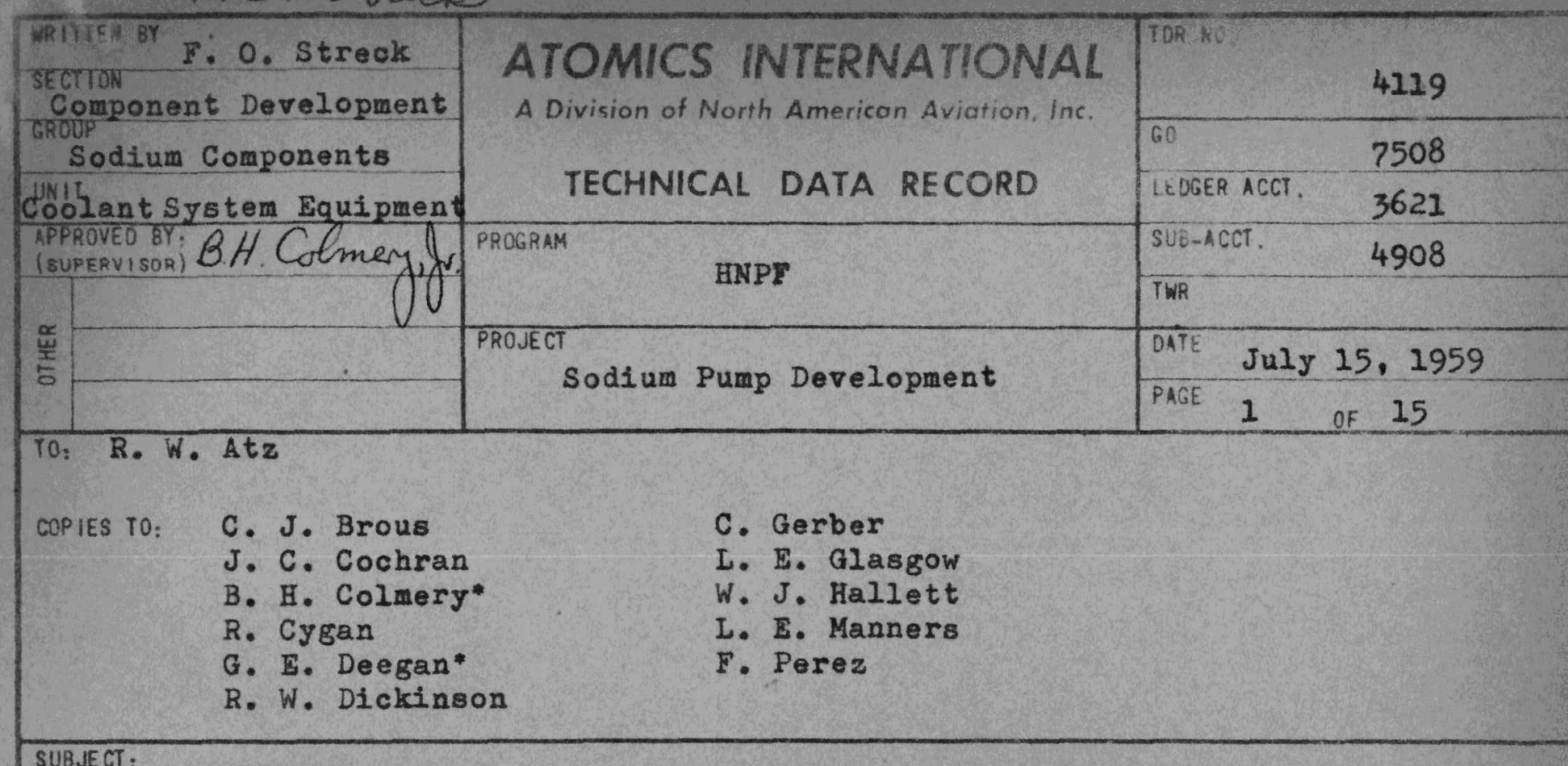

SUBJECT:

Performance Test of a Two-Coolant-Region Sodium Pump Shaft Freeze-Seal* CONTENTS:

I STATEMENT OF PROBLEM ............................ 1

II SUMMARY OF RESULTS AND RECOMMENDATIONS ...................... PAGE 1,2

III METHOO USED, DESCRIPTION OF EQUIPMENT, SAMPLE CALCULATIONS . . PAGE $3,4,5,6$

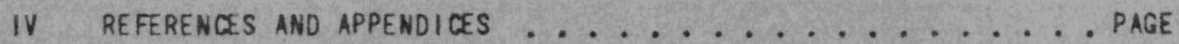

1 SUAIEMEMI OF PROBLEM

The operation of the freeze-seal type sodium pump requires a shaft freeze-seal capable of retaining sodium. A prototype two-coolant-region freeze seal for application on HNPF sodium pumps had been designed fand constructed. It was required that it be tested under environmental conditions to determine its operating characteristics and sodium retaining capabilities.

II SUMMARY OF RESULTS AND RECOMMENDATIONS

\section{A. Results*}

The seal is capable of retaining sodium at $600 \% \mathrm{~F}$ with the shaft rotating at $1000 \mathrm{rpm}$. The sodium to gas differential pressure was 15 psi.

\section{Gas Leakage}

At normal seal temperatures a $\triangle P$ of 15 psig can be Impressed across the seal without signiflcant leakage of gas or sodium from the sodium side. Shaft speeds of from

This report covers work performed on freeze seal test stand number 1 and completed several months ago. It is being published for completeness and will be followed by a separate report on two series of tests on freeze seal test stand number 2 completed in May 1959. 
ATOMICS INTERNATIONAL

A Division of North American Aviation, Inc.
4119

DATE JUIY 15,1959

PAGE -2 OF 15

zero to $1000 \mathrm{rpm}$ have had no effect upon gas leakage from the sodium side of the seal. Gas inleakage will occur to the sodium side of the seal during normal operation when a differential pressure of $3 \mathrm{psig}$ or greater is impressed across the seal. Definite rates, however, were not established. Due to lack of driving power to the shaft (which would be stalled if the seal were kept too cool) it could not be established whether lower seal temperatures would prevent an inleak of gas during operation.

2. Motor Load

Motor load is linear and decreases with increasing sodium temperature. Approximately 1.4 kilowatts are required to drive the shaft at $1000 \mathrm{rpm}$ with the sodium at $500^{\circ} \mathrm{F}$. (See Figure 4) A comparison of the frozen seal power requirements with an unwetted seal motor load is shown in Figure 6 .

3. Seal Cooling Load

At a sodium temperature of $500^{\circ} \mathrm{F}$ the total seal cooling load is 3.1 kilowatts. It can be seen from Figure 5 that the seal cooling load is directly proportional to the sodium temperature.

\section{Seal Temperature}

Temperature measured across the seal decreased generally exponentially from the inner to the outer end of the seal (See Figure I. and 2.) Reverse tetralin flow in the lower region of the seal produced lower average temperatures throughout the seal.

5. Sodium Extrusion

During this test about 6 in. ${ }^{3}$ of sodium were found to have extruded along the pump shaft into the gas filled space above the seal (See photo 7508-5410A). This leakage occurred at various times and under variable conditions so that the cause of this loss was not established.

\section{B. Recommendations}

This test did not closely simulate the conditions to be encountered in the freeze seal pump. It is recommended that further tests be performed on this type seal in the second freese seal test stand. The thermocouples should be 
ATOMICS INTERNATIONAL

A Division of North American Aviation, Inc.
NO. 4119

DATE JuLy 15,1959

PAGE $-3 \quad$ OF 15

re-arranged to measure more accurately the location of the molten sodium interface.

In a sodium freeze-seal for a sodium-pump shaft, leakage of liquid sodium is prevented by frozen sodium. A cooling system is required to freeze the sodium in the seal and to keep it from being melted by heat conducted from liquid sodium.

The type of seal tested had two tetralin cooling loops mounted side-by-side on the pump shaft. Principal advantages of the tworegion seals over single-region seals are that location of the liquid/Bolld interface can be more accurately determined and more precisely controlled. The two-region seal is therefore more flexible and more reliable. Since all connections are made outside the seal, it is unlikely that tetralin leaks could occur at joints in the vicinity of the seal.

Satisfactory operation of two-region type freeze seals has previously been demonstrated on 2 -inch solid pump shafts. The HNPF pump shaft is 5 inches in diameter and is hollow to a diameter of 4 inches. The purpose of the tests reported herein is (I) to determine seal operating conditions, temperature gradients across the seal, location of the liquid/solid sodium interface, seal cooling requirements, seal friction loss, and (2) to indicate that a two-region shaft freeze seal will operate satisfactorily on a 5 -inch hollow, pump shaft.

\section{A. Methods}

Tests were run with the shaft at 0 through $1000 \mathrm{rpm}$, with tetralin flow rates of 4.75 to $9.49 \mathrm{lb}$. per. min. through each region of the seal, and with bulk liquid sodium temperatures of $500,550,575$ and $600^{\circ} \mathrm{F}$. Corresponding HNPF design values are $835 \mathrm{rpm}$ and $1000^{\circ} \mathrm{F}$.

Temperatures at selected points on the exterior seal coolant channel walls (See Figure 3.) were measured with thermocouples and the temperature gradients plotted. (See Figure 2) The location of the liquid/solid interface was taken as that point at which the temperature was $208^{\circ} \mathrm{F}$.

Seal cooling requirements were determined by measuring coolant inlet and outlet temperatures and coolant flow rates and computing the amount of heat removed. At the temperatures encountered during the tests, the heat capacity and specific gravity of tetralin are almost constant and no correction was made for these changes.

Pump shaft speeds were measured with a stroboscope. Pump 
ATOMICS INTERNATIONAL

A Division of North American Aviation, Inc.
NO. 4119

DATE JULY 15, 1959

PAGE $\quad 4 \quad$ OF 15

power was measured with a wattmeter.

The ability of the seal to retain sodium was determined by visual observation through a heat-resistant glass viewing port. (see photograph 7508-5410A)

\section{B. Description of Equipment}

The equipment used in these tests consist of a twocoolant-region freeze seal and a 5-inch diameter hollow shaft. In the lower coolant region tetralin flows through 6 turns of $1 / 2$-inch $\times 035-i n c h$ wall tubing coiled around a perforated sleeve and contained within a cylindrical housing. In the upper coolant region of the seal tetralin flows through a hollow Nange concentric around the shaft. The 5 -inch shaft was hollow along the portion which passed through the seal. The shaft wall thickness was 0.250 -inches at the hollow section. The radial clearance between the shaft and the seal was 0.0625 -inches. (See photographs 7508-5402 A and B.)

\section{Description of Test Rig}

The test rig consisted of a static sodium pot heated by tubular heaters, a surge tank which could be pressurized to impress a differential pressure across the seal, a stuffing box which contained the seal, and a bearing housing which supported the shaft and its driver. The driver was a 15 HP direct current variable speed motor.

\section{Description of Instruments}

(a) All speed measurements were made with a Strobotac measuring device. This instrument incorporates a neon light which can be adjusted to flash at a predetermined rate. When the light is directed upon the rotating shaft coupling and it appears to stop, the spedd is equal to the number of flashes per minute. Accuracy of this derice $1 s \pm 1 \%$.

(b) Seal sodium temperature measurements were made with chromel-alumel stainless steel sheathed thermocouples and were recorded on an L \& N Speedomax 6-point recorder. The probable error in the thermocouples is $\pm 4^{\circ} \mathrm{F}$. The probable error in the recorder is $1 / 4$ of $1 \%$ of full scale reading. Other

temperature measurements were made with chromel-alumel glass-and-asbestos-insulated thermocouples. The temperatures were indicated on a Brown 24 point 
ATOMICS INTERNATIONAL

A Division of North American Aviation, Inc.
NO.

4119

DATE JuIy 15,1959

\section{PAGE}

5 OF

indicator. Probable error of the thermocouple is $+4^{\circ} \mathrm{F}$. Probable error of the indicator is $1 / 4^{-}$of $1 \%$ of full scale reading. Tetralin $\Delta \mathrm{T}$ measurements were made, using chromel-alumel differential thermocouples connected to a slidewire potentiometer. Probable error of thermocouple $\pm 4^{\circ} \mathrm{F}$. Probable error the instrument $1 / 2$ of $\bar{I} \%$ of 1 III scale.

Tetralin flow measurements were made using a Fisher-Porter variable area flowmeter. Probable error $\pm 1 \%$ of full scale.

Motor ammeter and voltmeter data are accurate to $\pm 5 \%$ of full scale.

\section{SAMPLE CALCULATIONS}

Cooling load lower seal

Assuming that all heat removed from the lower seal is removed by the flowing tetralin, the cooling load of the seal is given by,

$$
Q=M \times C_{p} \times \Delta T
$$

where,

$$
\begin{aligned}
Q & =\text { Cooling load on lower seal region in BTU/min. } \\
M & =\text { Tetralin flow through lower seal region in } 1 \mathrm{~b} . / \mathrm{min} . \\
C_{p} & =\text { Specific heat of tetralin, in } \mathrm{BTU} / \mathrm{lb}=0.40 \\
\Delta T & =\text { Difference in tetralin inlet and outlet temperatures at } \\
& \text { lower seal region, in } \mathrm{F} .
\end{aligned}
$$

from known data,

Flowrator full flow $=5 . ? \mathrm{gpm}(100 \%)$ and, tetralln weighs $8.06 \mathrm{lb} / \mathrm{gallon}$ at $95^{\circ} \mathrm{F}$ so, for a flowrator reading of $20 \%$, the mass flow rate is $(0.20)(5.7)(8.06)=9.2 \mathrm{lb} / \mathrm{min}$.

For the differential thermocouple used, a reading of $0.022 M V$ corresponds to a $\triangle T$ of $1 \circ \mathrm{F}$.

Thus, for a differential thermocouple reading of $0.765 \mathrm{MV}$ and a flowrator reading of $20 \%$ (observed at $450 \%$ sodium temperature and $1000 \mathrm{rpm}$ shaft speed)

$$
\begin{aligned}
Q & =(9.2)(0.40)\left(\frac{.765}{0.022}\right)=12800 \mathrm{BTU} / \mathrm{min} . \\
& =2.25 \mathrm{KW}
\end{aligned}
$$


ATOMICS INTERNATIONAL

A Division of North American Aviation, Inc.
NO. 4119

DATE JU1Y 15,1959

PAGE

6 OF 15

It can be seen from Figure 5 that the variation of the cooling load appears to be linear with sodium temperature. It can also be seen from the data below that the friction load of the seal varied with the shaft speed, but not with sodium temperature.

\section{Friction Cooling Load of Seal}

Speed $\mathbf{r p m}$

Na temperature $\mathrm{F}$

Tetralin flow $1 \mathrm{~b} . / \mathrm{min}$. upper Tetralin flow $1 \mathrm{~b} . / \mathrm{min}$. lower cooling load KW
1000

450

9.49

9.49

2.93

$$
\begin{aligned}
& 2.935 \mathrm{KW} \\
& \frac{1.525 \mathrm{KW}}{1.410 \mathrm{KW}}
\end{aligned}
$$

1000

500

9.49

9.49

3.02

\begin{tabular}{l}
$3.020 \mathrm{KW}$ \\
$1.605 \mathrm{KW}$ \\
\hline $1.415 \mathrm{KW}$
\end{tabular}

$$
\begin{array}{r}
0 \\
450 \\
9.49 \\
9.49 \\
1.525
\end{array}
$$

$1000 \mathrm{rpm}$ $1000 \mathrm{rpm}$

friction load

Cooling load KW

Na temperature ${ }^{\circ} \mathrm{F}$

Tetralin flow $1 \mathrm{~b} . / \mathrm{min}$. upper Tetralin flow lb/min. lower 
TEMPERATURE DISTRIBUTION ALONG SHAFT FREEZE SEAL

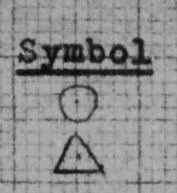

$\frac{\text { Shaft speed xpm }}{1000}$

Tetralin rlow 1b. min.

Upper
6.9
9.9
Lower 6.45

9.22

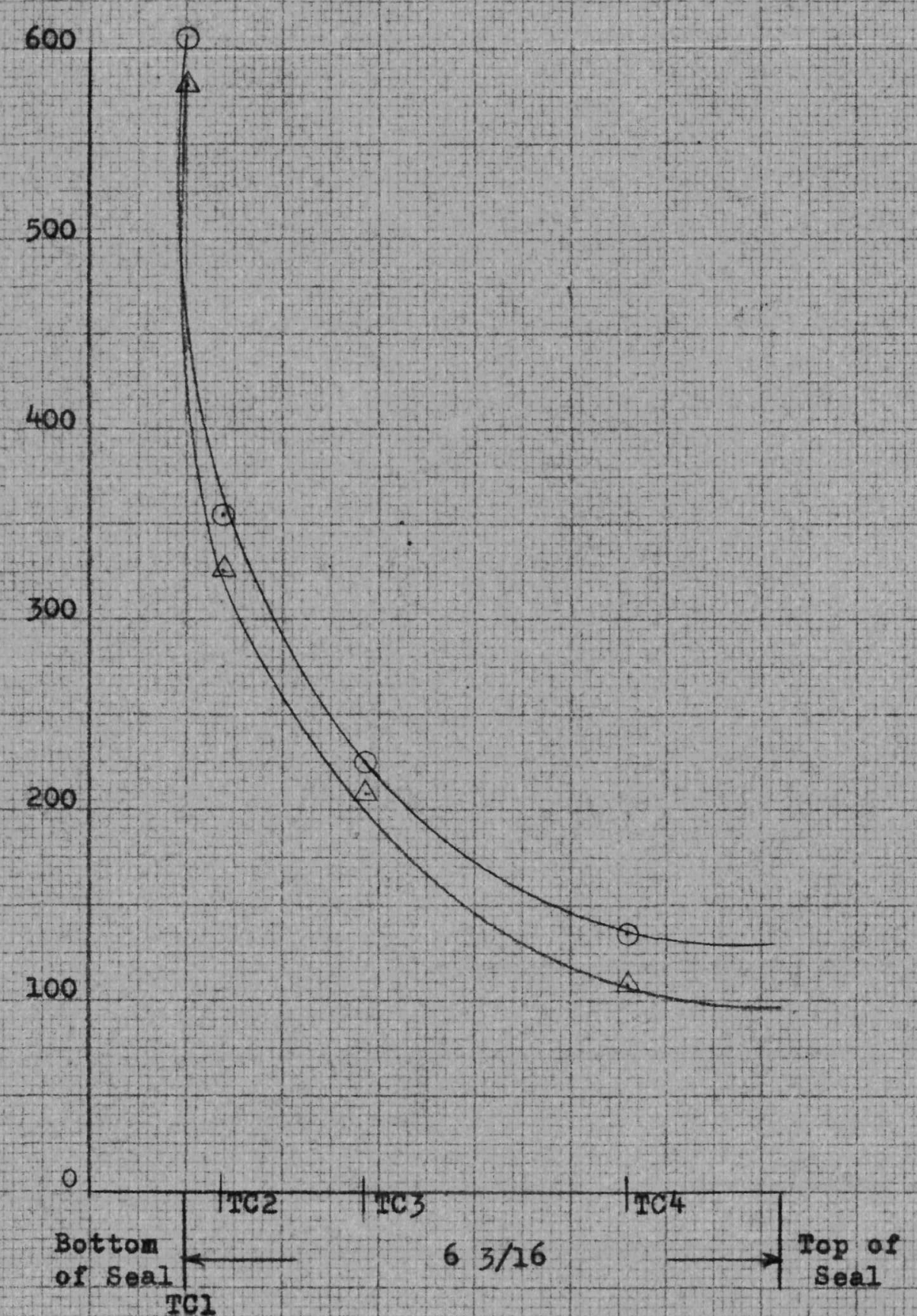


JuIy 15,1959

TEMPERATURE DISTRIBUTION ALONG SHAFT FREEZE SEAL

Reverse vs. Forward Flow

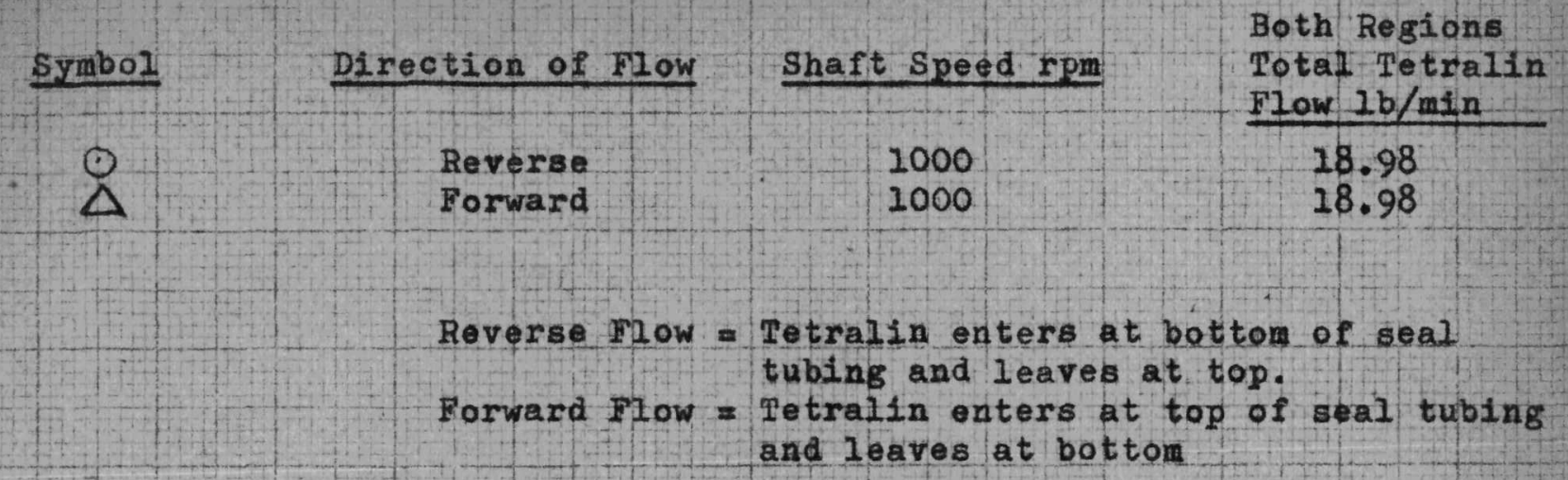

(3)

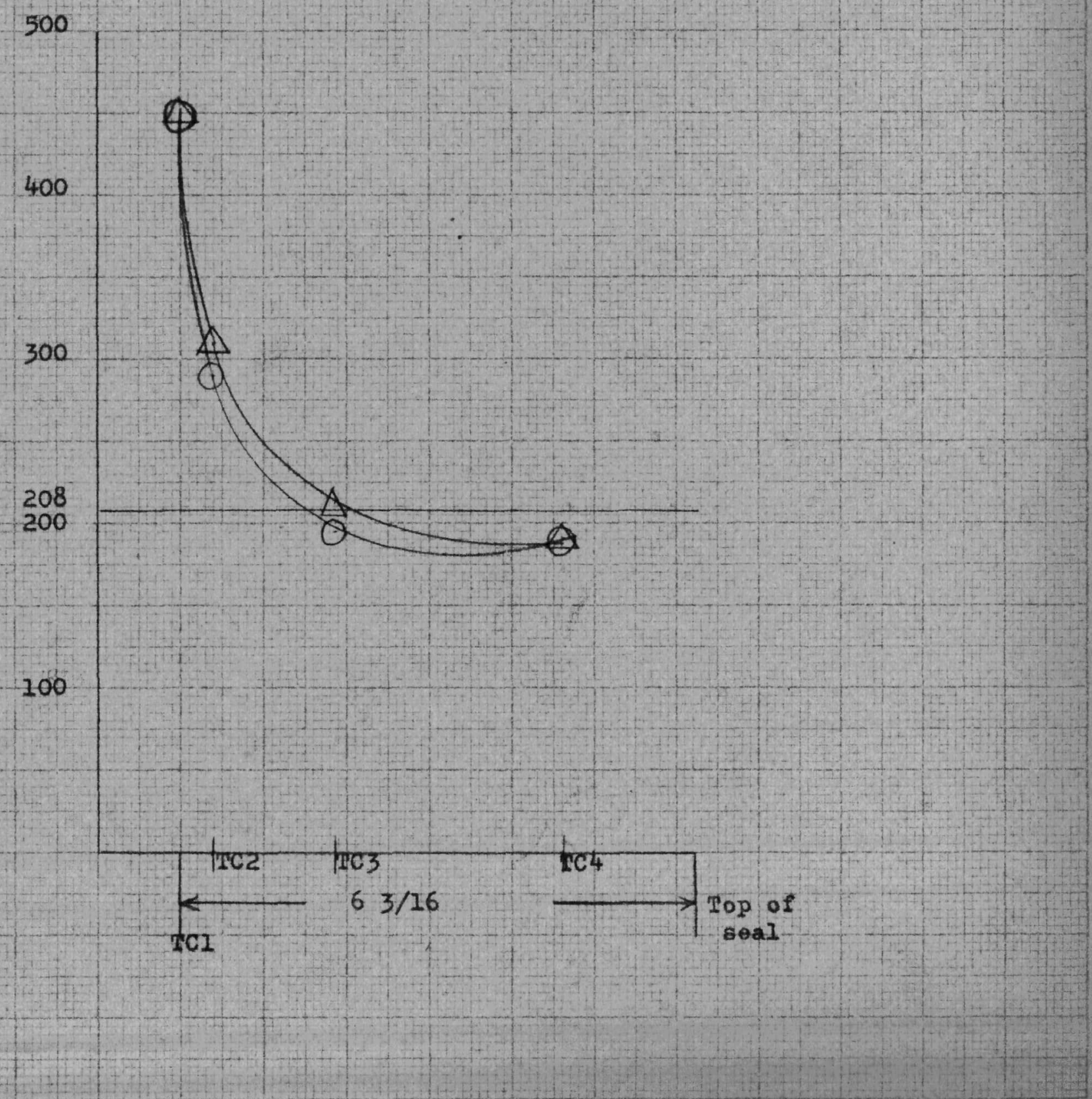




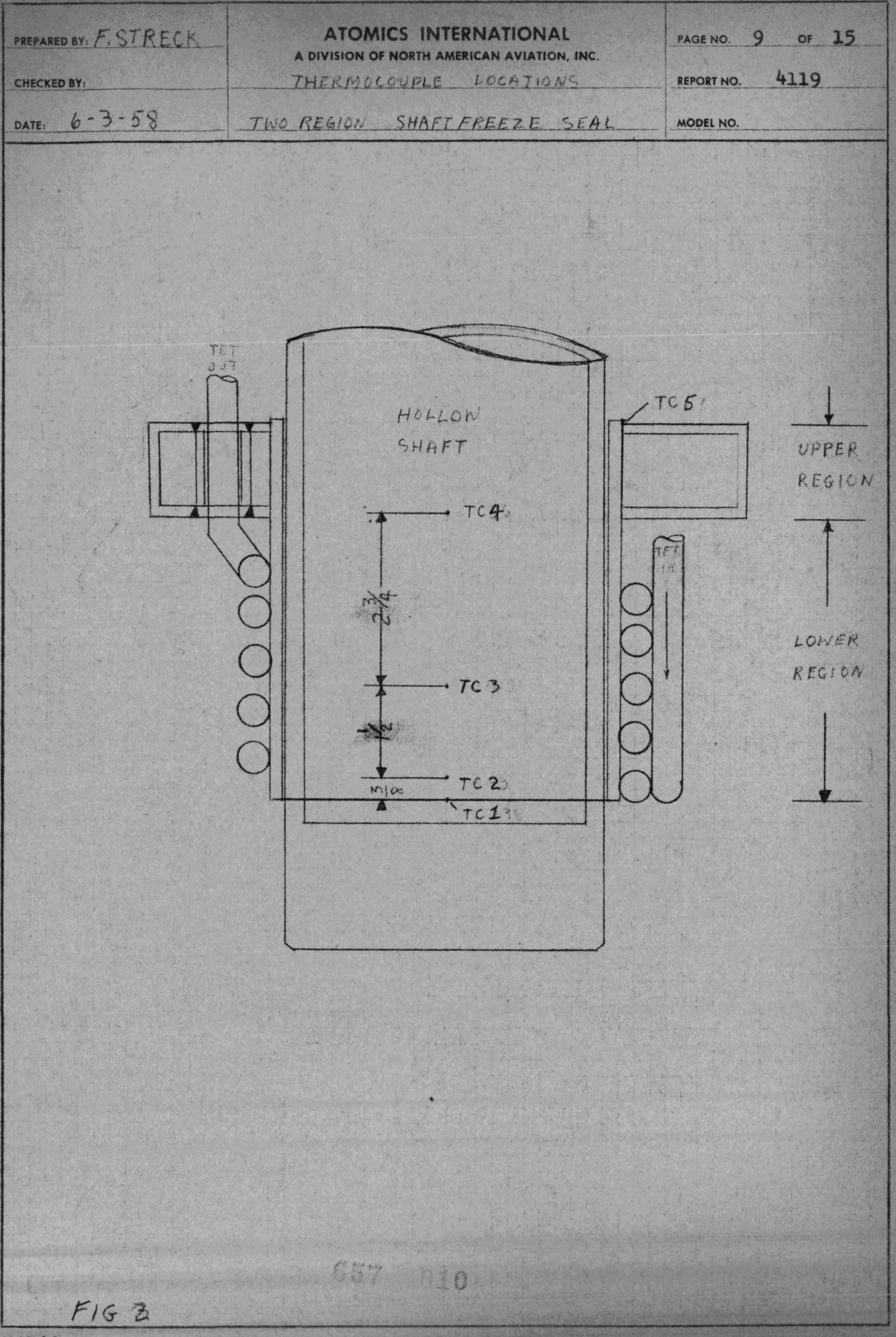


Motor Load vs Sodium Temperature

Shaft Speed rpi - 1000

Tetralin Flow (Both Regions) \#min - 18.98

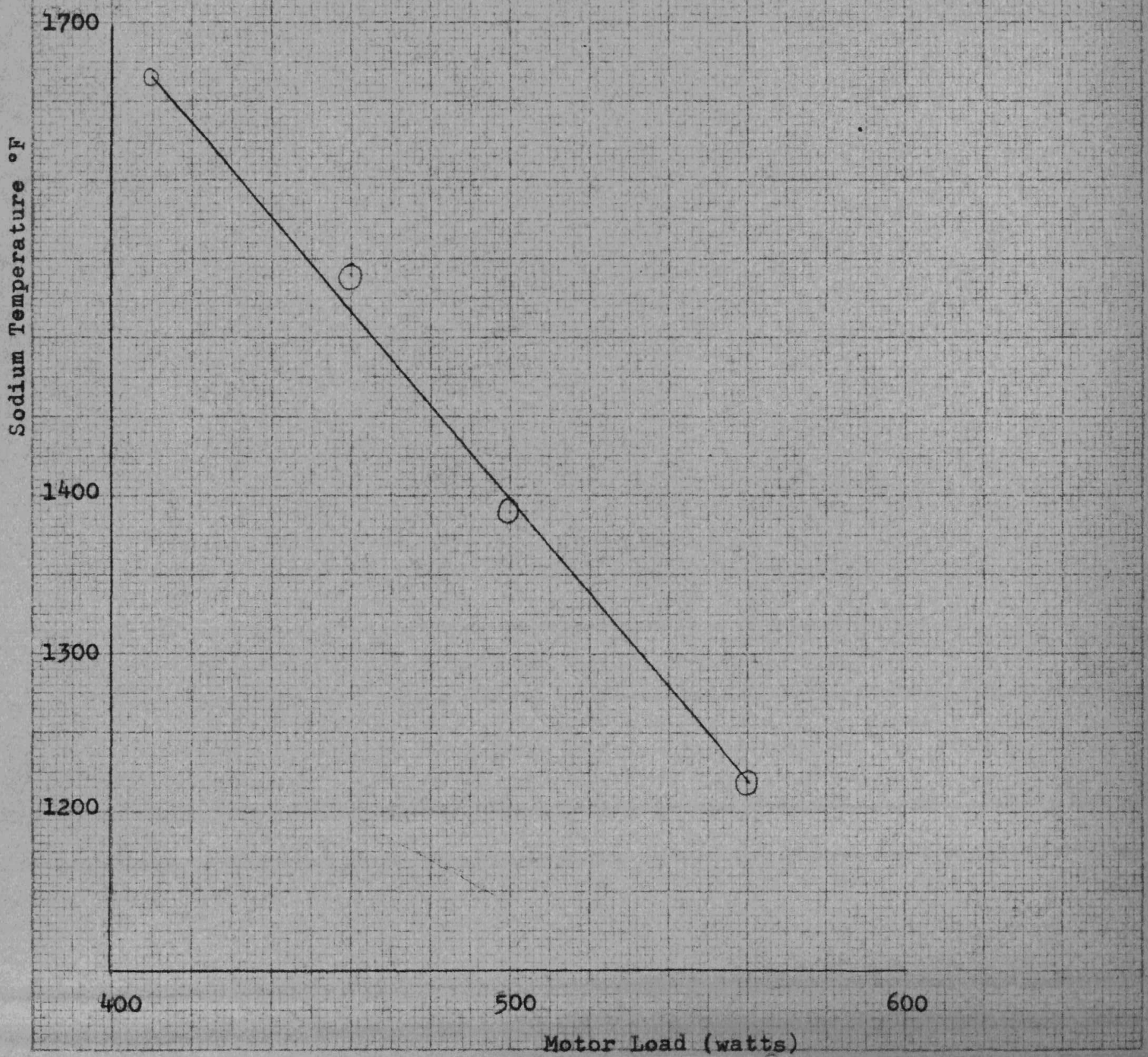


Page 11 of 15

TDR No. 4119

July 15, 1959

TOTAL SEAL COOLIKG LOAD VS SODIUM TEMPERATURE

Na Teap. or

410

450

500

560
Total Tetralin Flow \#/min.

18.98

18.98

18.98

18.98
Speed rpm 1000 1000 1000 1000

1

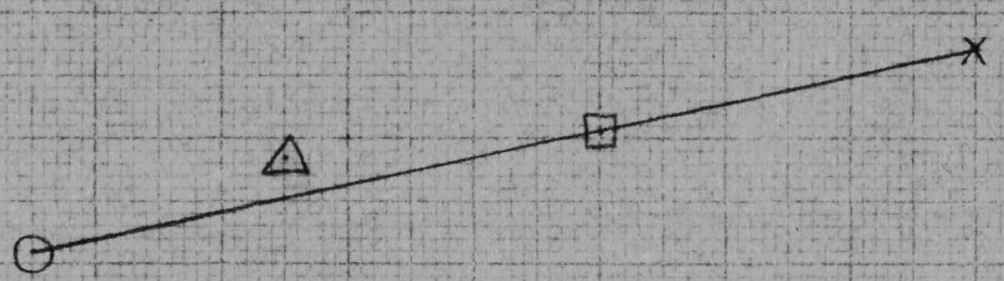

2

Na Temperature from tc 6 


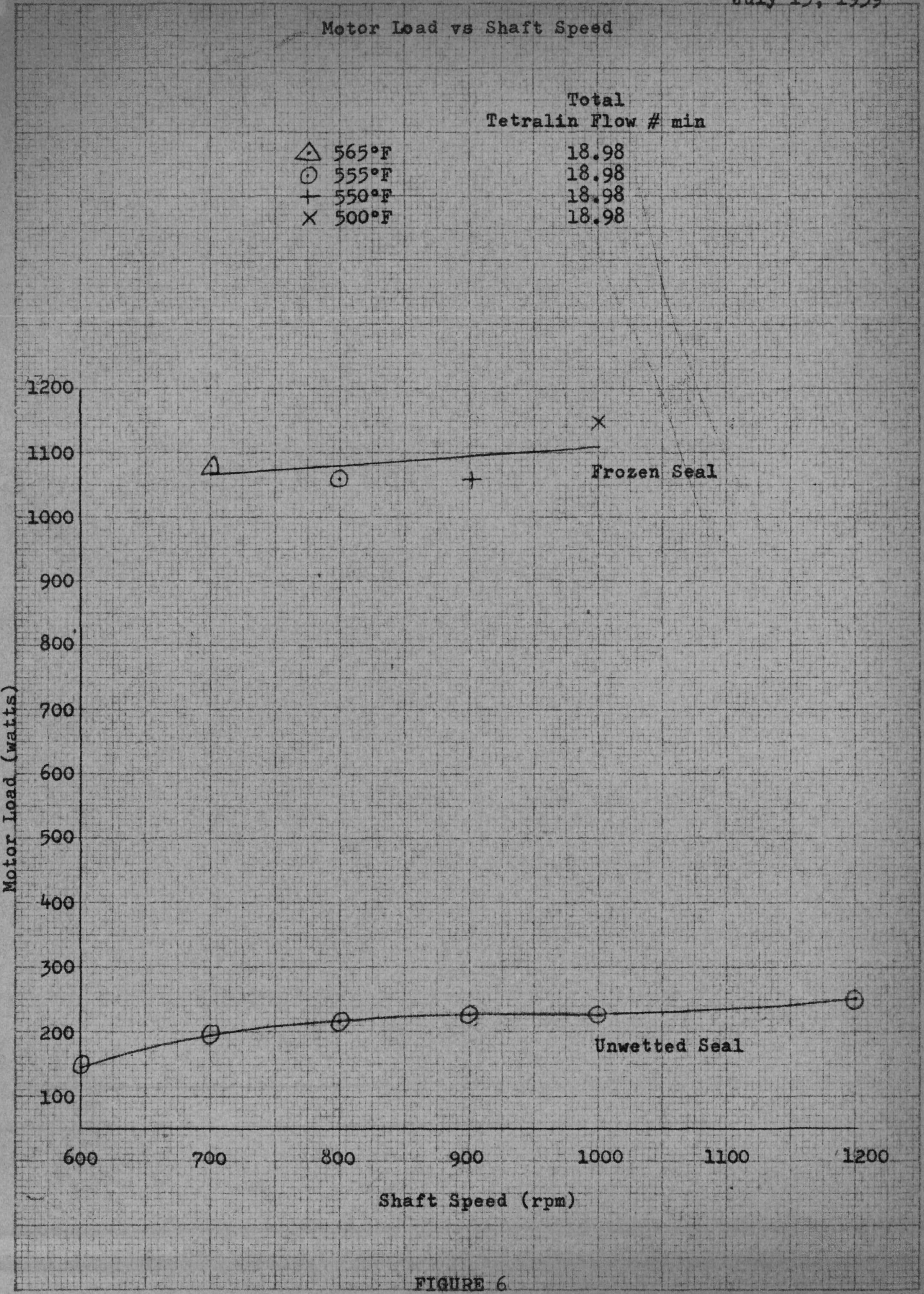


TDR 4119

Page 13 of 15
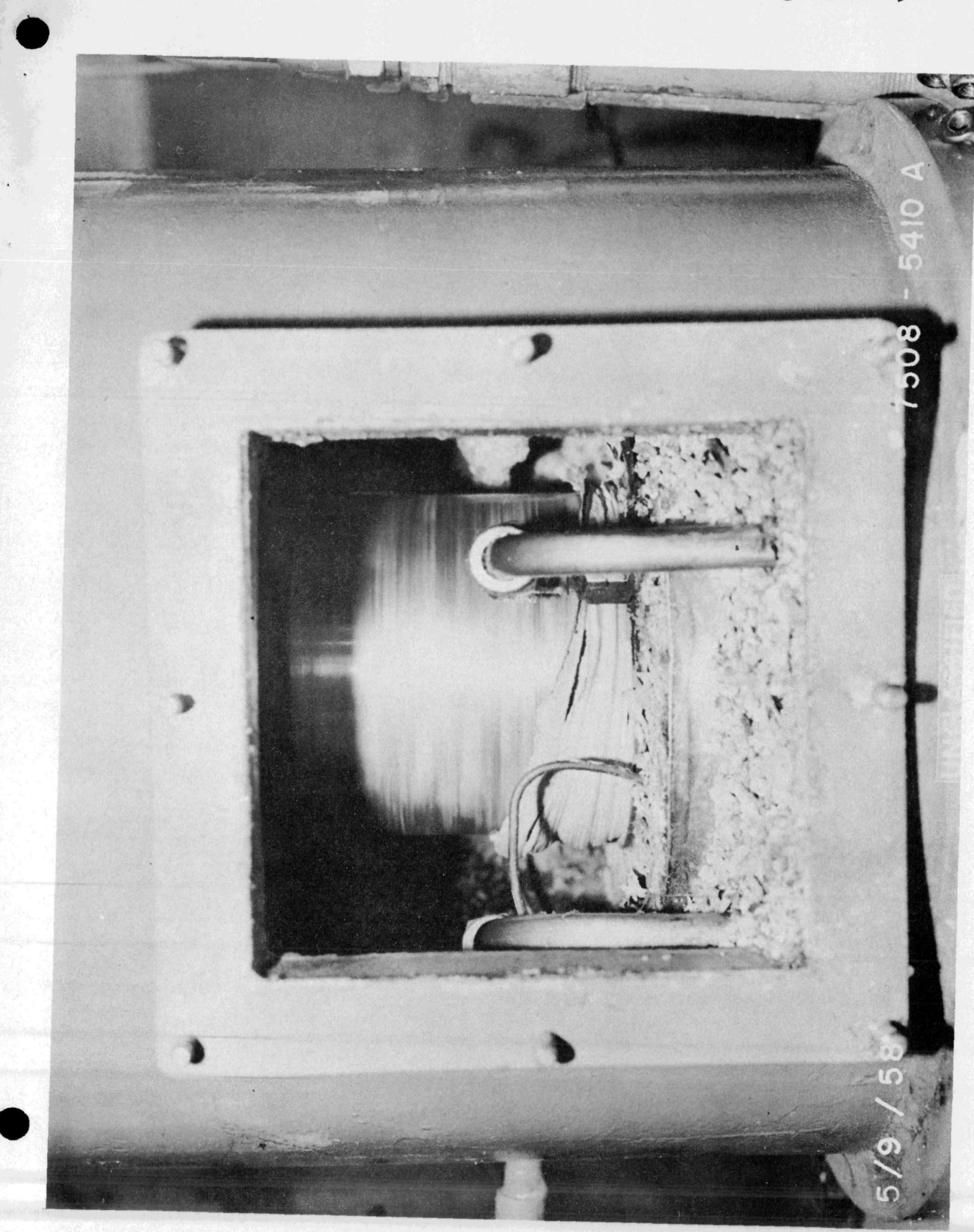
TDR 4119

Page 14 of 15

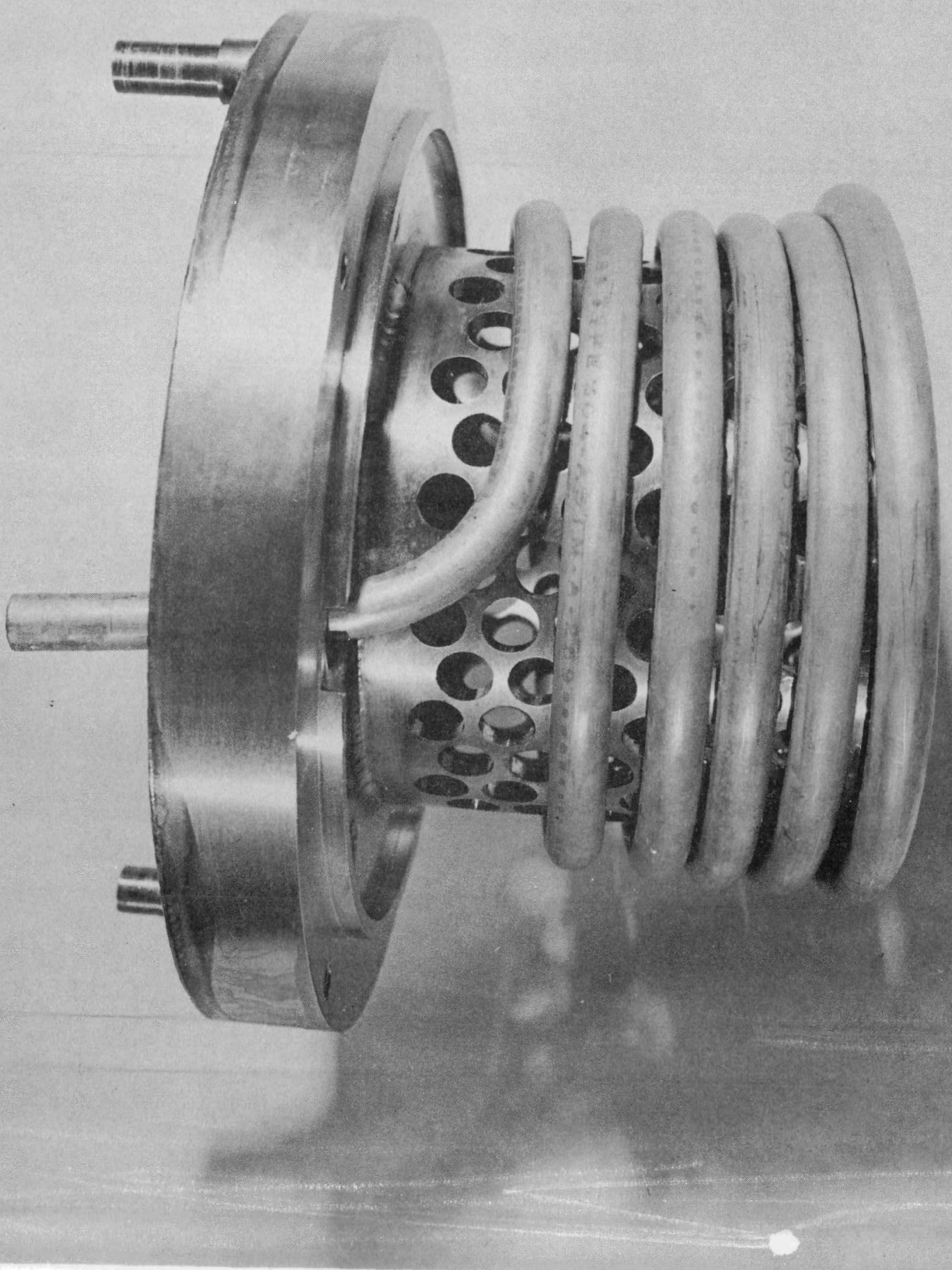


TDR 4119

Page 15 of 15

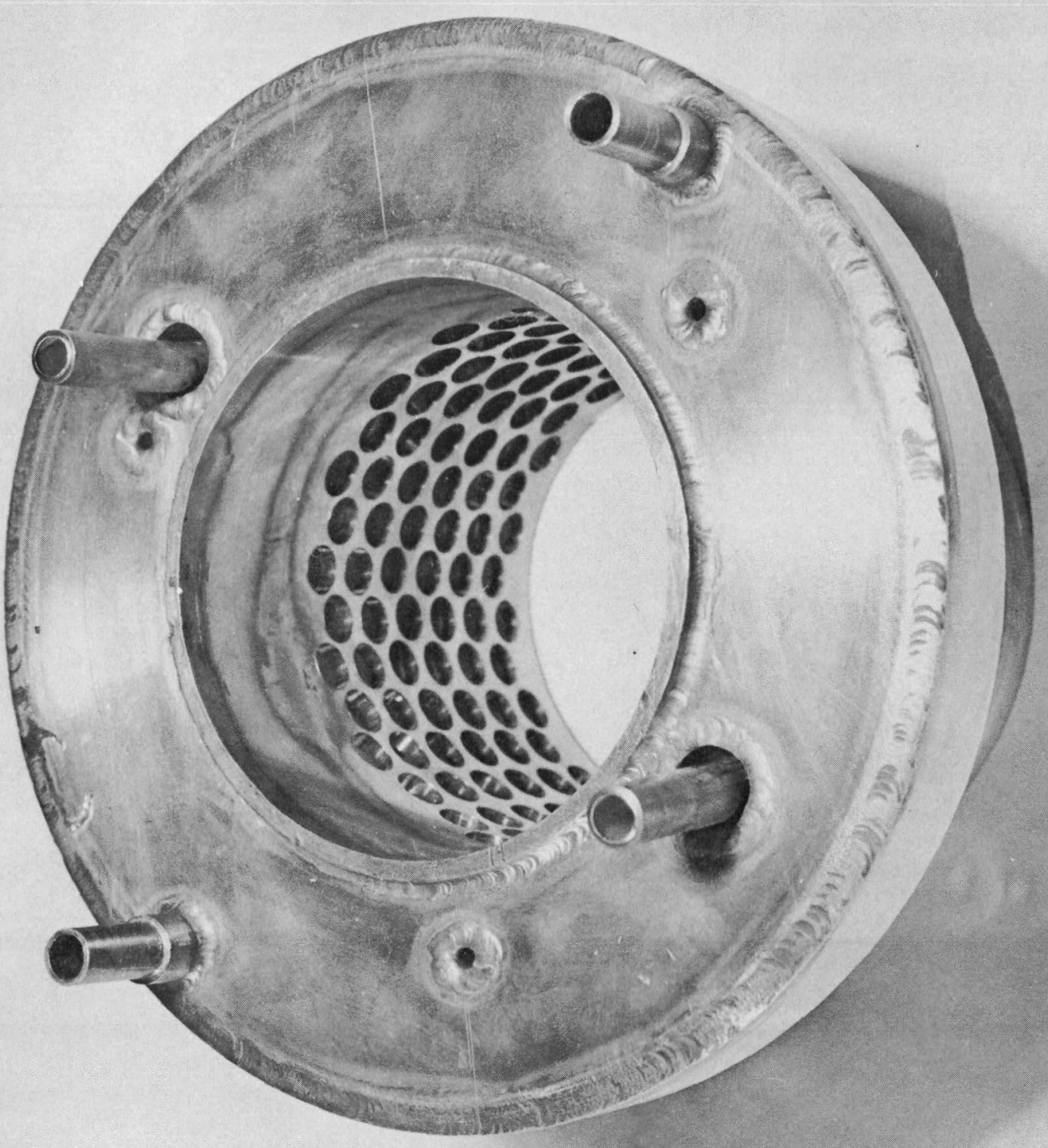

